\title{
La acción en las obras cinematográficas colombianas de ficción, antes de los diálogos de paz (1960-2011)
}

\author{
Recibido: 08 de septiembre de 2015 \\ Aceptado: 15 de abril de 2016 \\ Publicado: 30 de noviembre de 2016
}

\author{
Jorge Prudencio Lozano Botache \\ jplozano@uniquindío.edu.co \\ Universidad del Quindío (Colombia)
}

\begin{abstract}
Resumen: A continuación se denotará la presencia de los componentes de la "Red Conceptual de la Acción" (Ricoeur, 2000) en una amplia muestra de obras cinematográficas de ficción (es decir, basadas en la puesta en escena), previas a la iniciación de los diálogos para poner fin al conflicto armado, tomando como punto de partida a la década del sesenta (en la que nacieron los grupos insurgentes). Se consideraron solo obras con instancias narrativas $^{1}$ e historias ostensiblemente colombianas y de al menos de 70 minutos de duración, que es un tiempo a partir del cual se considera legalmente que una obra es de largometraje en Colombia.
\end{abstract}

Palabras clave: Agente, motivaciones y finalidades, circunstancias, caracteres temporales, recursos simbólicos.

\begin{abstract}
The presence of "Conceptual Network of the Semantics of Action" components (Ricoeur, 2000) will be denoted in a large sample of cinematographic works of fiction (ie, based on the staging) previously made to dialogue to end the conflict, taking as a starting point the sixties (when insurgent groups were emerge). It was considered only films with narrative instances and ostensibly Colombian stories and with at least 70 minutes long, time required for being legally considered a long film in Colombia.
\end{abstract}

1 Para Chatman (1990), las instancias narrativas son todas las contribuciones individuales y colectivas que propician a la elaboración de la obra como un todo acabado. 
Key words: Agent, Motivations and Finalities, Circumstances, Temporary Marks, Simbolic Resources.

\section{Introducción: objetivos, metodología e hipótesis}

A menudo las obras cinematográficas de ficción producidas en Colombia son estigmatizadas por supuestamente concentrar sus temáticas o bien en la frivolidad o bien en la violencia derivada del narcotráfico y el conflicto social y armado. No obstante, lo que suele subyacer en esta opinión es una cierta superficialidad en el análisis de las relaciones entre los personajes y el devenir de los colombianos, inmerso, ciertamente en contextos cargados de violencias y frivolidades pero nada exento de los grandes problemas de la condición humana: el amor, el odio, el poder, la avaricia, la venganza, la muerte, entre otros.

En la perspectiva de este documento, más que la representación o el registro mismo de imágenes y sonidos, lo que importa es hacer referencia a las implicaciones culturales que tienen las acciones con las que se narrado cinematográficamente a Colombia antes de los diálogos de paz. Interesa la reflexión suscitada por la alusión audiovisual a la dinámica de las identidades humanas que inciden en la transformación de otras análogas, durante lo que Ricoeur (1983/2000) denomina prefiguración, configuración y refiguración de la identidad mediante la narración ${ }^{2}$.

Se analizó un acervo de obras cinematográficas realizadas entre 1960 y 2011, a partir de los componentes de la noción de red conceptual de la acción: agentes, motivaciones, finalidades y circunstancias. Se recurrió a una metodología que le da relevancia a la acción porque esta, como concepto (o como "red conceptual de la acción", según Ricoeur) por una parte, permite comprender a la noción de "condición humana" que protagoniza la sociedad y la cultura y que se asume en esta investigación (es decir, el ser humano como un ser de acción que agencia motivaciones como el amor o el odio y finalidades como la venganza o el poder, siempre dentro de ciertas circunstancias) y, por otra parte, es un núcleo plausible para el análisis de las artes narrativas, que es como se asume en este caso a las obras cinematográficas. De esta forma, la acción proporciona lo que se registra en los acontecimientos y en la memoria pero también se puede registrar sobre otros soportes materiales y culturales.

En esta aproximación al cine colombiano, por razones prácticas, sólo se mencionarán dos documentales de menos de setenta minutos (Tulia, de San Pedro de Iguaque y La ley del Monte) que tienen gran importancia desde el punto de vista de su manera de narrar a la

2 Ricoeur (2000: 113-168) describe tres momentos de la narración: a) mímesis I o "prefiguración”, en la que el sujeto narrador reconoce las manifestaciones concretas de los componentes de la red conceptual de la acción que desea narrar; $b$ ) mímesis II o "configuración", en la que el sujeto narrador configura una trama narrativa combinando imaginativamente a tales componentes; y c) mímesis III o "refiguración", en la que el lector y, para efectos de esta tesis, el espectador observa, lee o interpreta la narración elaborada y la contrasta con su propia identidad. 
de la red conceptual de la acción, más otros de más de setenta minutos: Nuestra voz de tierra, memoria y futuro, Camilo, el cura guerrillero y Gamín. Esta arbitraria selección, sin embargo, no constituye un juicio de exclusión sobre otras obras documentales de menor duración y gran sentido cultural. Por considerarlas significativas para los propósitos de este artículo, se mencionan algunas pocas obras de antes de 1960 (María, Flores del valle, Bajo el cielo antioqueño) y otras tantas del 2012 (Porfirio y Roa).

Esta suerte de estado del arte parte de considerar que en las narraciones cinematográficas se manifiesta el impulso ancestral de los seres humanos, consistente en la necesidad de dar cuenta o de autonarrar su propio accionar. El cine es un arte caracterizador de nuestra época, así que aportar a una mayor comprensión de las relaciones entre los personajes y relatos cinematográficos (dentro de los contextos en que ellos han surgido y que además referencian) resulta importante, más que para incidir sobre el acervo de la crítica cinematográfica hecha en Colombia, para dilucidar el punto de vista que nuestra época expresa a través de los cineastas, acerca del conflicto social y armado en nuestro país. No hacerlo despilfarra una oportunidad de reflexionar en este momento coyuntural en el que se habla incluso de lo que debe suceder cuando se entre en el llamado posconflicto.

\section{Red conceptual de la acción}

El concepto de acción según lo definió Ricoeur (2002) es la capacidad de hacer que algo suceda y para explicarlo de manera operativa, este autor se apoya en el filósofo finlandés George H. von Wrigth quien, a su vez, recurre a la teoría de los sistemas dinámicos para afirmar que la acción es la intervención de al menos un ser humano (llamado "agente") sobre un sistema de relaciones con otros seres humanos, animales y objetos. Estos sistemas siempre son parciales respecto del universo; nunca estamos en relación con todo el universo: la acción es particular y concreta y la articulación de una serie de acciones sobre un sistema constituye al curso de los acontecimientos. La acción es un fenómeno en el que se despliegan tanto la identidad de los individuos como la intersubjetividad ${ }^{3}$.

En realidad la acción consta de varios componentes que conforman lo que se puede denominar la "red conceptual de la acción" (Ricoeur, 2000): un agente, que es el sujeto (individual o social) que realiza la acción; las motivaciones, que son las causas internas que llevan al agente a actuar; la finalidad, que es el propósito buscado por el agente; las circunstancias, que son las relaciones con otros agentes y que condicionan a la acción; y los conflictos que resultan de las interacciones.

3 Ricoeur es une autor ampliamente conocido como hermeneuta y es común recurrir a él como estudioso de los significados del mundo de la vida a través del lenguaje escrito. No obstante, este filósofo establece una analogía entre el texto escrito y la acción, proponiendo a esta última como un "cuasitexto", en el que también se puede registrar y leer el acontecer humano. Este trabajo apropia a las herramientas conceptuales de Ricoeur para adecuar una metodología de análisis cinematográfico llamada "hermenéutica de la acción". 
A su vez, la red conceptual de la acción es interpretada desde dos aspectos culturales: los caracteres temporales o hechos significativos para un grupo social y los recursos simbólicos o valores con los que tal grupo social interpreta a la realidad. Ni los caracteres temporales ni los recursos simbólicos pertenecen a la red conceptual de la acción. Los caracteres temporales son hechos que se marcan en el transcurrir del tiempo, en contraste con el reposo y la espera. Con ellos se construye la trama y dentro del devenir social constituyen los hechos a los que se les da relevancia desde particulares concepciones o contextos de la historia y que juegan un papel muy importante para interpretar las acciones tanto individuales como colectivas. Pueden ser abordados por la narración cinematográfica, bien sea de manera directa como una re-creación del presente o del pasado; bien sea como alusión o acontecimiento circunstancial; bien sea como contexto narrativo o como atmósfera dentro de un relato audiovisual con otros propósitos ${ }^{4}$.

Los recursos simbólicos son aquellos valores, símbolos, significados, imaginarios, temas y demás referentes culturales con los cuales una cultura o un individuo interpreta y evalúa a las acciones. En este caso a las que se narran cinematográficamente, ya sea identificándose o distanciándose de ellas. Esos recursos simbólicos se pueden proyectar tanto en la narración en su conjunto como en alguno de los aspectos específicos del lenguaje cinematográfico, tales como imágenes, iluminación, ambientes, música, ruidos, diálogos, desempeño actoral, entre otros. Los recursos simbólicos amplían notoriamente las relaciones estéticas y en general culturales del espectador con la narración cinematográfica al otorgarle significado tanto a la acción como a su contexto.

\subsection{Tipos de agentes en las obras cinematográficas colombianas}

El agente es un ser humano o humanizado, colectivo o individual que vehiculiza a la acción. Equivale al personaje y como individualidad proviene de la dramaturgia clásica, en la que el protagonista es quien tiene un propósito y el antagonista es quien se le opone. Esta última distinción es tanto un recurso técnico como filosófico y cultural, válido tanto para la ficción como para el documental. Un agente o personaje es encarnado en la escena por un actor. Técnicamente, individualizar a la acción ejemplariza bien sea para que el espectador se identifique o para que se distancie del personaje, con lo cual, dicho sea de paso, se subraya la función pedagógica del drama. Esta es una manera de viabilizar a la narración dramática.

Vselodov Pudovkin propuso por medio de sus obras cinematográficas a comienzos de los años veinte en la Unión Soviética el concepto de "tipo", que consiste en construir un

4 Aunque Ricoeur (2000) menciona a los caracteres temporales, no los explica claramente. Sin embargo, en un texto ulterior (ibidem, 2002: 242-256) dedica un aparte a lo que denomina "la iniciativa", con la que se puede precisar un poco más el concepto de "caracteres temporales". Dicha iniciativa consiste en interrumpir intencionadamente el estado de contemplación y reflexión al que conduce el paso del presente fenomenológico (el día, la noche, las semanas, los años) y permite pasar del "tiempo del alma" al "tiempo del mundo", mediante acciones que configuran al presente cosmológico; en conclusión, la iniciativa permite marcar caracteres temporales o registros sobre una representación lineal del tiempo. Tales hechos tienen significado ético o político y algunos adquieren especial importancia histórica que, a su vez, vuelve a la contemplación y la reflexión sobre el tiempo fenomenológico para enriquecerla. 
personaje individual adjudicándole rasgos psicológicos, sociológicos y físicos de distintos individuos pero pertenecientes a un mismo grupo social. Desde ese criterio Pudovkin hizo una obra maestra titulada La Madre, basada en la novela homónima de Gorki pero la noción de tipo ha sido muy utilizada en la comedia y el personaje del vagabundo (creado por Charles Chaplin) es un ejemplo cumbre porque no se esclerotiza, sino que (al contrario) se versatiliza para explorar múltiples facetas de la condición humana. En cambio, en la comedia colombiana se ha probado varias veces la construcción de "tipos", con resultados sin mucho brillo aunque inocultables, como José en El taxista millonario (Nieto, 1979), gordo, pobre, ingenuo, sufrido, suertudo y honesto; o Mariano, en La pena máxima (Echeverri Roa, 2001), empleado público de bajo rango, apasionado por el fútbol, terco, desleal y desgraciado.

La construcción de un personaje individual tanto para un texto dramático o guión, como para la interpretación actoral, cuenta con una larga tradición técnica que involucra saberes prácticos específicos de la dramaturgia en tanto oficio y de otros campos disciplinares, como la psicología. No obstante, en este caso resulta pertinente resaltar el sentido filosófico que tiene la noción de individuo, bien sea predestinado por fuerzas naturales, sobrenaturales o inclusive sociales como en la antigua tragedia griega; o bien libre de ellas, dueño de su razón y su conciencia y enfrentado a las circunstancias o lanzado a sus propias pasiones y angustias.

Entre los predestinados, El triángulo de oro (Pinilla, 1984) muestra a unos exploradores codiciosos, esquemáticos, predestinados a morir víctimas de monstruos y plantas carnívoras, ante las cuales no sirve ninguna de sus astucias; por otra parte, Andrés y Margaret, los hermanos incestuosos en Carne de tu carne (Mayolo, 1983) poseídos por fuerzas sobrenaturales, cometen crímenes vampirescos; la predestinación es común en personajes envueltos en historias legendarias, como le ocurre a Adel en La boda del acordeonista (Bottia, 1985); algo similar ocurre en otra parte, la predestinación social se aprecia En tiempo de morir (Triana, 1985), obra en la que Juan Záyago, pese a su sensatez, estaba condenado a matar a Julián Moscote y a morir a manos de Pedro.

Entre los personajes que toman decisiones por sí mismos, está Adolfo León Gómez, el provinciano enamorado y osado que en Visa USA (Duque, 1986), acepta su fracaso y decide quedarse con su novia; El padre Gabriel en La pasión de Gabriel (Restrepo, 2009) quien parece confiar sólo en su conciencia y se rebela hasta contra los preceptos de su religión. Pedro Rey, en El rey (Dorado, 2004), un hombre de bajos recursos económicos, pero astuto y sin escrúpulos, se interesa por las actividades ilícitas; con perversa solidaridad le ofrece trabajo a varios de sus amigos y menesterosos hasta convertirse en un mafioso avaro y sangriento. En el cine colombiano es frecuente encontrar a este tipo de personajes, elaborados acaso con intenciones reflexivas acerca de nuestra sociedad, como sucede con Roberto Hurtado, el magnate que manda a asesinar personas para obtener la sangre que requiere para sobrevivir en Pura sangre (Ospina, 1982); o en relación con la historia, como ocurre con León María Lozano en Cóndores no entierran todos los días (Norden, 1984) sectario y fríamente cruel.

Otros, menos frecuentes en el cine nacional, son los personajes marcadamente fantasiosos como Rafaelito, en Los niños invisibles (Duque, 2001) quien quiere hacerse invisible para 
estar más cerca de Martha Cecilia, la niña de la que está enamorado; o los personajes picarescos, como Jaime Florez en El embajador de la India (Ribero, 1987) quien se aprovecha de la credulidad de unos gobernantes esnobistas y de un pueblo arribista para hacerse pasar por un diplomático de aquel país asiático.

Por su parte, Lisa, en Malamor (Echeverri, 2003) se aventura a vivir entre su apasionado amor por Hache y unas atormentadas búsquedas existenciales. Este tipo de personajes ha sido menos común en el cine nacional, como en una suerte de indiferencia hacia la exploración de las profundidades psicológicas del colombiano. Hay varias obras cinematográficas centradas en historias de amor, como Tiempo para amar (Nieto, 1980), Una mujer con suerte (Nieto, 1991) o Bésame mucho (Toledano, 1995) que son más bien descripciones de lugares comunes en los sentimientos y comportamientos de la clase media.

Es precisamente en el grado de autonomía del personaje donde empieza a colarse lo ideológico en dependencia del ensalzamiento que el discurso de la obra haga del voluntarismo y el heroísmo. En el cine colombiano no es fácil identificar ejemplos que pertenezcan a estas opciones; no obstante, hay algunos rasgos esquemáticos de ello en el intrépido Kapax, el hombre leopardo (Rincón y Sambrell, 1981); más claros están en el libertador de la obra animada Bolivar, el héroe (Rincón, 2003) y de manera paródica en El Man (Trompetero, 2009), poseedor de una gran fe asumida con la inmediatez de la cotidianidad popular. Sin embargo, es más claro el ejemplo de La pasión de Gabriel (Restrepo, 2009), obra en la que este sacerdote católico renuncia a toda prebenda que se oponga a sus convicciones de servicio aunque ello le depare sufrimiento y luego la muerte.

En cambio, son más frecuentes los personajes que aunque toman iniciativas, son apabullados por las circunstancias. Esto se observa en Clemente y Firulais en Raíces de piedra (Arzuaga, 1961) condenados por su pobreza a no encontrar las soluciones a los problemas más elementales de la búsqueda de dignidad; y en Augusto en Pasado el meridiano, del mismo director de la ultima obra mencionada (1966), víctima de la indolencia social. Lo mismo sucede con Toño y Paulina, en La primera noche (Restrepo, 2003) pese a su dignidad, están condenados a ser perseguidos, a ser pobres y desgraciados por haber nacido campesinos, en una zona de influencia guerrillera y en un país en conflicto armado; en La sombra del caminante (Guerra, 2004), Mañe y su amigo el silletero, pese a haber sido mutuamente víctima y victimario estuvieron condenados a sobrevivir juntos. También está en estas circunstancias Mónica en La vendedora de rosas (Gaviria, 1998) huérfana que pese a su espíritu de trabajo y sentido de la dignidad en medio de las turbulentas costumbres de los habitantes de la calle, siempre estuvo desamparada hasta ser inevitablemente asesinada.

También ronda a lo ideológico el grado de conciencia social crítica del personaje hacia su contexto histórico, social y político, como lo pregonó Lawson (1949) o por el contrario su defensa del establecimiento. En La estrategia del caracol (Cabrera, 1993), Perro Romero (un tinterillo o abogado empírico) y Jacinto (un veterano anarquista español) enfrentan y burlan al poder económico, a las que consideran leyes injustas y en general al establecimiento. 
Sin embargo, Colombia no cuenta con grandes relatos cinematográficos de héroes fundantes, a no ser que se considere a María Cano (Loboguerrero, 1990) sobre la líder sindical y social de comienzos del siglo XX; o Bolívar soy yo (Triana, 2002a) que, sin embargo, tiene un marcado acento paródico y políticamente satírico, en el que la figura de “el Libertador" es empleada emblemáticamente por muchas fuerzas culturales, económicas, sociales y políticas de intereses divergentes y hasta opuestos o desquiciados, como ocurre con el actor Santiago Miranda, personaje de este relato, que oscila entre la interpretación actoral y el delirio de considerarse él mismo Simón Bolívar. En este caso también vuelve a ser pertinente la animación digital Bolívar, el héroe (Rincón, 2003) que es una suerte de biografía del libertador con apoyo dramatúrgico en dos personajes alegóricos: Tiránico (que es antagonista) y Américo, que es un esclavo muy apreciado por Simón.

Por otra parte, la afirmación del establecimiento la han realizado personajes de historias convencionales y defensas más acérrimas del status quo suelen ser desarrolladas en obras cinematográficas por lo general financiadas por un organismo estatal o entidades afectas a él. En Colombia se acercarían a este grupo las obras audiovisuales de tipo institucional que ha producido el ejército nacional para televisión a manera de seriados.

En la llamada Unión Soviética por los años veinte, el propio Eisenstein se manifestó en contra de la dramaturgia que promovía el individualismo y, desde su concepción marxista, hizo dos obras maestras ya mencionadas: Octubre (1927) y El acorazado Potemkin (1925), en las que si bien se identifican agentes individuales en algunas escenas, como Kerensky en la primera y Vakulinchuk, en la segunda, en muchos sentidos los dos relatos son protagonizados por las masas en tanto agente colectivo de la acción cinematográfica.

En Colombia, El río de las tumbas (Luzardo, 1964) es un ejemplo interesante, que muestra situaciones pintorescas de un pueblo pequeño en la que aparecen diferentes personajes que articulan situaciones sin que nadie llegue a ser francamente protagónico. Otro digno ejemplo de este grupo es el documental Nuestra voz de tierra, memoria y futuro (Rodríguez y Silva, 1982) en la que los indígenas quienes analizan sus propios mitos, lo contrastan con la explotación y al despojo a que han estado sometidos e identifican a sus explotadores y se disponen a asumir las riendas de su historia. En este caso también operan aspectos técnico-dramatúrgicos, disciplinares (como la ciencia política o la antropología), filosóficos (como la opción por el sujeto colectivo) e ideológicos, como la esperanza en un futuro mejor.

En alguna medida, la ya citada La estrategia del caracol (Cabrera, 1993) es, al mismo tiempo, una obra coral, en la que un grupo de individualidades se enfrenta al status quo y reclama el derecho a quedarse en una vivienda, dado que han habitado en ella durante muchos años. Colombia (país rico en diversidad cultural y en historias comunitarias) puede tener una rica veta dramatúrgica en este tipo de agentes (los colectivos) con grandes y pequeñas epopeyas. 


\subsection{Una mirada a las motivaciones y las finalidades}

Las motivaciones y las finalidades están estrechamente relacionadas. Las primeras son fuerzas volitivas, ético-morales, intelectuales, incluso coercitivas o patológicas, en todo caso ubicadas en el interior de los agentes o personajes; las segundas son fuerzas narrativas constituidas por los personajes mismos cumpliendo propósitos o ejecutando proyectos. Desde el punto de vista filosófico, las motivaciones y finalidades ponen en evidencia la discusión acerca de si tiene sentido que los sujetos se fijen propósitos o no, lo cual, al mismo tiempo proyecta implicaciones ideológicas precisamente a partir de lo que los agentes hacen o dicen.

Actualmente, este aspecto está relacionado con la discusión entre el sujeto moderno y el posmoderno. Se supone que el primero está motivado por el humanismo, guiado por valores como la libertad y la razón, y asume como finalidad proyectos afincados en la noción de progreso; una distorsión de este paradigma tiene como motivación a la ambición individualista y como finalidad a la instrumentación de la naturaleza y las personas, la acumulación de capital y el poder; el segundo tiene motivaciones dispersas o incluso no las tiene y, por tanto, tampoco se plantea finalidades unívocas y mucho menos de largo aliento.

En el cine colombiano hay solo algunos pocos personajes de motivaciones clásicamente humanistas, quizás porque aquí la modernidad tiene unos rasgos particulares, distintos a los de la modernidad europea. Sin embargo cabe destacar al Perro Romero y a Jacinto de $L a$ estrategia del caracol (Cabrera, 1993), quienes argumentan razones en defensa del derecho y la libertad; los teatreros de Los actores del conflicto (Duque, 2008), cuyo propósito es realizarse como artistas, dentro del respeto a los derechos ciudadanos; el sacerdote de La pasión de Gabriel (Restrepo, 2009), quien promueve la justicia y la honestidad en el manejo de recursos y asuntos públicos. También son modernos, en el contexto colombiano, Toño y Paulina, jóvenes campesinos que en La primera noche (Restrepo, 2003) aspiran, él a obtener la libreta militar para después conseguir un trabajo y progresar (aunque no lo logre) y ella a sacar adelante a sus dos hijos (aunque tampoco lo logre).

Estas mismas motivaciones modernas están parodiadas, aunque sin mucho brillo, por la vía de la comedia en la ilusión de José en El taxista millonario (Nieto, 1979) quien desde la noción de progreso aspira a salir de pobre, no para hacerse poderoso, sino tan siquiera para solventar su subsistencia básica, asediada por el arribismo y el consumismo. Igualmente paródico es el jovencito de $\mathrm{El} \mathrm{Man} \mathrm{(Trompetero,} \mathrm{2009),} \mathrm{quien} \mathrm{con} \mathrm{varios} \mathrm{lugares} \mathrm{comunes}$ y también en el contexto de la híbrida modernidad a la colombiana, defiende a la justicia y procura el bienestar del prójimo por medio de cierta fraternidad y un valor pre-moderno, como es la fe (en este caso en el "Divino niño"), puesta al servicio ya no sólo de la aspiración a progresar, sino tan solo de vivir dignamente, lo cual lo lleva inclusive a practicar el trueque, que al ser una dinámica económica también premoderna, aparece (en medio de la caricatura) como una alternativa válida ante el deterioro crítico de las condiciones de vida en la ciudad.

Caso singular es el de Manuel en Los colores de la montaña (Arbeláez, 2010), un niño que, por serlo, no tiene un gran propósito moderno en términos de lo que Kant llamó "la 
mayoría de edad", es decir, en términos de ser ya un sujeto autónomo, pero sí está en esa ruta, por la vía de la formación que le dan su familia y la sociedad, más la educación, recibida en la escuela; de hecho, él está motivado con el fútbol, desea convertirse en un arquero y se aferra a un balón como su gran propiedad. Su finalidad es conservarlo, aún corriendo ingenuamente algunos riesgos. Que al final su familia se lo lleve quien sabe para dónde, huyendo de la violencia (aunque tampoco haya sido una acción autónoma de Manuel) sí lo encarrila dentro del deseo de progreso que tienen su madre y su padre y que con toda seguridad él ha asimilado.

La distorsión (o instrumentalización, como diría Habermas) de las motivaciones y finalidades humanistas se observa en personajes como León María Lozano, quien en Cóndores no entierran todos los días (Norden, 1984) alienta a su libre albedrío con valores católicos bastante rigurosos y conservadores que eleva a la categoría de principios; con ellos mismos organiza clandestinamente a hombres armados llamados “pájaros” procedentes del partido conservador para asesinar a los liberales, quienes antes le habían servido. En esta misma tónica, Pedro Rey, en El rey (Dorado, 2004) impulsado por la ambición se torna violento, traiciona a su esposa y hasta manda a matar a su mejor amigo, el "pollo". Este mismo tipo de motivaciones y finalidades se evidencian en Gerardo, el neófito y violento narcotraficante que primero introduce en su negocio al ingeniero Santiago Restrepo y después lo traiciona secuestrándolo, en Sumas y restas (Gaviria, 2004); a la postre Santiago cobra venganza acribillando a Gerardo. Un caso más de ambición e instrumentación humana es el de El Orejón, Peñaranda y Benitez en Perro come perro (Moreno, 2008), quienes se destrozan emocional y físicamente disputándose un botín. Incluso en La estrategia del caracol (Cabrera, 1993), Holguín (el adinerado empresario, aún en ejercicio de los principios modernos de iniciativa individual y libre empresa) manifiesta expresamente sus desmedidas ambiciones de poder y de dinero, las cuales los llevan a promover el desalojo violento de la antigua casa en disputa con sus moradores. Varios de estos, a su vez, también están fuertemente motivados por la fe religiosa, que es pre-moderna, aunque defienden de manera liberal su derecho a la vivienda.

No obstante, Julián, en Terminal (Echeverri, 2000) se sumerge en el proceso de superación de una ruptura amorosa; Vega, en Al final del espectro (Orozco, 2006) tiene intensas motivaciones (en este caso fóbicas y angustiantes) sin una gran finalidad, más allá de superar sus propios tormentos. Esta mujer se destruye interiormente hasta sucumbir por completo; Karen, en Karen llora en un bus (Rojas, 2011) resuelta a no seguir siendo un simple apoyo para su marido, del que depende económicamente (y sin preparación previa) decide a vivir con astucia y picardía los avatares de la supervivencia en las calles de Bogotá; Ofelia, en PVC-1 (Statholopoulos, 2007) es un ejemplo de motivaciones por coerción (en la acepción de Ricoeur), ya que las motivaciones no siempre son eufóricas. La bomba que le han atado al cuello los hombres de Benjamín tiene un límite de tiempo para explotar. Su angustia no es (ni podría ser) patológica ni intelectual ni mucho menos volitiva. Sus desvaríos son la consecuencia de aquella penosa situación.

Por otra parte, solo algunas pocas obras plantean personajes sin motivaciones ni finalidades, según las tendencias de la postmodernidad, aunque en contextos que no son 
megalópolis pero sí mundos articulados a la globalización por marginados que parezcan. Un ejemplo de este último grupo es Tulia, en el documental Tulia, de San Pedro de Iguaque (Echeverri, 1992), un personaje que parece haber estado perdido en el tiempo y el espacio, disolviendo durante muchos años su personalidad, primero en los intereses de su esposo (ya muerto) y ahora en el entorno rural, donde no parece existir pasado ni futuro, ni siquiera la muerte.

Otro ejemplo es Don Daniel, en El vuelco del cangrejo (Ruiz, 2009), quien frustrado y escéptico con el país parece no tener motivaciones más allá de irse (lo cual no es exactamente moderno) y su débil finalidad es encontrar una manera de emigrar, sin que al final tampoco lo logre. Ni siquiera alcanza su re-encuentro consigo mismo. Un caso especial es Ancizar López, personaje de El arriero (Calle, 2009), quien en principio es un neoliberal aunque pobre, que tiene claramente definida como finalidad salir de la pobreza por medio del narcotráfico. Así logra acumular dinero y manipular a dos mujeres, (quienes a la postre se confabulan para tomar venganza). Al final, derrotado y hastiado con los espejismos de la riqueza, este hombre termina yéndose a subsistir como pescador artesanal en un pueblo alejado, sin un gran propósito moderno y sí con una carga de escepticismo.

Otro caso especial es Eliseo en Satanás (Baiz, 2007) cuyas motivaciones más fuertes, el resentimiento, el odio e incluso su pasión amorosa hacia la adolescente Natalia, tienen orígenes patológicos derivados de su traumática experiencia militar en Vietnam. Pese a que también tiene algunas otras motivaciones intelectuales (como la lectura y el ajedrez) estas están supeditadas a las primeras. También pese a que en esta obra cinematográfica se entrelazan las historias de otros personajes, como Paola y el padre Ernesto, con finalidades razonables y de progreso, Eliseo es un personaje urbano sin rumbo, interiormente destruido, víctima de una guerra entre fuerzas contemporáneas, y residente en una ciudad compleja y socialmente abigarrada como Bogotá.

\subsection{Entre circunstancias}

Como se ha sugerido arriba, las acciones no son inanes, sino que constituyen y dinamizan el curso de los acontecimientos, que al articularse dentro de una trama configuran narraciones ( $c f$. Ricoeur, 2002). Entonces, la narración es la manera como fluyen las vivencias o se articulan los conflictos de los agentes entre sí, consigo mismo o con la naturaleza, por el solo hecho de existir y verse abocado a reaccionar. Técnicamente, las circunstancias se revelan mediante escenas o interacciones de un agente con su entorno físico o con otros agentes; disciplinarmente también resultan importantes las particularidades del contexto social o natural, el "tipo" y las singularidades de los personajes.

Las circunstancias configuradas dentro de una narración constituyen el relato y permiten estructurar al tiempo relatado, según la concepción de "tiempo" que sugiere Ricoeur al afirmar que el tiempo humano está constituido por los acontecimientos humanos, en contraste con el tiempo cósmico marcado por lo que le sucede a los meteoritos, planetas y galaxias. Las circunstancias permiten configurar el relato desde el guión, pasando por 
la puesta en escena y concretándose en la edición. Las escenas o interacciones exponen a las valoraciones que evidencian los personajes, a las decisiones que toman y a las consecuencias de lo que hacen a lo largo de todo el relato.

Por ejemplo, León María Lozano en Cóndores no entierran todos los días (Norden, 1984) empieza como ayudante en una librería, luego logra establecer una venta de quesos y cuando se dan las circunstancias, se convierte en escudero demencial de sus ideas políticas para matar a sus rivales, no menos apasionados que él. Doña Gertrudis Potes, líder de los liberales, lo apodó el "Cóndor" por ser el más grande de todos los llamados "pájaros" o matones. Este hombre escapa de algunos atentados y pone a salvo a su hija, enviándola a Bogotá, pero finalmente es asesinado precisamente por los liberales, quienes pacientemente habían esperado hasta encontrar la oportunidad de cobrar venganza.

En Confesión a Laura (Osorio, 1990), Santiago (un funcionario del gobierno) acepta ir a entregar el ponqué de cumpleaños (hecho por Josefina, su esposa) para Laura la vecina de enfrente. Estando allí, se ve obligado a permanecer en casa de la cumpleañera debido a que en la calle hay amotinamientos y francotiradores que podrían matarlo. Entonces Santiago y Laura se confiesan los sentimientos que habían reprimido hasta entonces, mientras Josefina "hierve" en su desesperación. Pedro Rey, en El rey (Dorado, 2004) luego de haber alcanzado fama, dinero y poder (maltratando y humillando a todos los que se cruzaron en su camino) es traicionado y acribillado por uno de sus servidores, el teniente Pulgarín.

Acerca del guion, Pudovkin afirmó que este debe ser de hierro, es decir, seguido al pie de la letra durante el rodaje, con lo cual coloca al guión como el elemento más fuertemente caracterizador de la narración cinematográfica, supeditando a él tanto a la puesta en escena como a la edición. Es seguro que la interpretación considerada más literal fuera la del director, quien (al menos en su caso) era el mismo guionista aunque cabe la posibilidad de que el director de fotografía también tuviera tal misión, si se tiene en cuenta que guiones como el de La Madre hacían bastante énfasis en la fuerza expresiva de la imagen. Más allá de las propias obras de Pudovkin, es difícil encontrar ejemplos aplicativos del guion de hierro aunque hay una herramienta homóloga conocida como storyboard o historia dibujada en el escritorio, empleada con cierto rigor y frecuencia en la publicidad y con más flexibilidad en la producción cinematográfica como tal.

En el contexto de la cinematografía colombiana, $P V C$-1 (Staphilopoulos, 2007) es un relato que requirió (de cierta manera) un guion (si no de hierro en sentido estricto) por lo menos bastante riguroso, como quiera que la obra se realizó en un solo plano secuencia. En general, los documentales se distancian de la noción del "guion de hierro", como lo evidencian la ya citada Nuestra voz de tierra, memoria y futuro (Rodríguez y Silva, 1982), ejemplo de investigación paciente que permitió que la estructura de la obra final fuera emergiendo durante el proceso de producción y realización. Algo análogo tuvo que haber sucedido en Tulia, de San Pedro de Iguaque (Echeverri, 1992) que no se hizo con una comunidad, como la obra anteriormente citada, sino con una sola persona. Por su parte, Field (1984) propuso el llamado "paradigma", orientado a lograr que la obra cinematográfica realizada cautive la 
atención del espectador ${ }^{5}$. Según Field (de alguna manera inspirado en Aristóteles) un guion debe presentar a un personaje en acción y debe tener tres partes: un planteamiento de la historia, un desarrollo de la misma y una solución.

Pese a que muchos guionistas y directores (incluidos los colombianos) rechazan el rigor del paradigma, si se analizan con cuidado, sus propias obras presentan grandes coincidencias con él. Por ejemplo, en Soñar no cuesta nada (Triana, 2006) historia sobre unos soldados de la compañía Destroyer que encontraron en la selva una caleta de dólares escondidos por la guerrilla. Hacia los 28 minutos de transcurrido el relato, el soldado Porras expresa que no está de acuerdo con apoderarse de ese dinero. A continuación, el teniente le da la orden de guardar silencio al respecto y justo en el minuto 30 el soldado reprime su inconformidad y acepta la orden gritando ¡lancero! Este es el primer "plot point", con el que se concreta lo que Field denomina el "planteamiento". A partir de entonces ya no se relata la travesía de unos soldados sin dinero (con ilusiones juveniles y que persiguen a los guerrilleros) sino la obnubilación de un grupo de soldados que deciden apoderarse del dinero que encontraron y lo derrochan entre rencillas y juegos en la selva.

El punto medio tiene lugar cuando en pleno vuelo hacia la base militar, el soldado Lloreda denuncia que ha perdido su dinero y amenaza hacer explotar al avión con una granada. Un soldado declara que Lloreda no será capaz, pero este grita “¡Yo no soy ningún güevón!” Y a los 60 minutos exactos Lloreda es controlado por el teniente, pero también por el soldado Porras, que es el personaje principal. Este es el punto medio, a los sesenta minutos. Aunque ese acontecimiento no impide que los militares mantengan su dinero, sí empieza a sembrar dudas sobre lo que sucederá. A partir de ese momento la torpe ostentación de los militares los lleva a generar sospechas entre el alto mando.

El segundo gran plot-point tiene lugar a los 90 minutos exactos, cuando en un flashback explicativo, el soldado Porras llama a su joven esposa para informarle que huyó para no someterse a la ley. De esta forma, se le presenta con una justificación para aspirar a salvar a su familia de la bancarrota, justificación que contrasta con la suerte de los otros soldados y así deja planteada una discusión sobre la validez ética de lo hecho por todo el pelotón. A partir de ese momento empieza la cortísima solución de la historia, que consiste en que la joven esposa de Porras (acompañada de su pequeña hija) inicia el viaje de retorno a su hogar.

Por otra parte, aunque sin haber escrito una teoría, Luis Buñuel escribía sus guiones basado en su intuición, sin adoptar ninguna regla más que el gusto por esa intuición creativa confrontada con la de al menos una persona más, que en su caso fue muchas veces JeanClaude Carrière. En Colombia no son frecuentes las experimentaciones de este tipo y mucho menos las exitosas. Aún así se han dado algunos casos interesantes de este tipo de

5 Este paradigma, según su autor, ha resultado del análisis de la estructura de miles de guiones cinematográficos escritos dentro de la industria cinematográfica norteamericana y responde a los hábitos del público. Resulta interesante contrastar las implicaciones conceptuales de este paradigma, evidentemente operativo, con la teoría cognitivista de Bordwell (1985), pero también con el "modo de representación institucional" (MRI) propuesto por Burch (1987). 
experimentación, como La mansión de Araucaima (Mayolo, 1986) que tiene una cierta secuencialidad basada en Ángela, la adolescente que escapa de su labor protagónica en la filmación de un comercial para llegar a la mansión, donde al final se suicida. En la mansión se desencadenan una serie de situaciones que no se rigen por una causalidad explicable mediante la noción de conflicto desarrollado linealmente, sino más bien por el entrecruzamiento de las pasiones que fluyen instintiva y puntualmente entre aquellos personajes que se autodestruyen.

Muchos académicos y realizadores en diferentes partes del mundo han escrito recomendaciones técnicas sobre cómo escribir un guion, pero más allá de las preceptivas o sugerencias, algunas de ellas muy claramente expuestas, no constituyen propiamente una teoría con efectos comprensivos sobre la narración cinematográfica. De todas maneras, guionizar, filmar y editar las circunstancias son oficios y la estructura de una narración no garantiza ni el éxito ni el fracaso del relato, aunque haya algunas sugestivas, como la de La primera noche (Restrepo, 2003) que comienza cuando Toño llega a la casa de Nacho, donde deja su uniforme de militar y continua huyendo. A partir de entonces se observan en flashback y, al mismo tiempo, en paralelo con la progresión de la historia, los hechos previos a la deserción de aquel muchacho. Él estuvo enamorado de Paulina pero ella prefirió al hermano, Wilson, con quien tuvo dos niños. Toño quería obtener su libreta militar para después trabajar, pero Wilson prefirió irse con su tío (un jefe guerrillero) quien a su vez le pidió a su hermana (madre de Toño y Wilson) que se marchara porque la situación se tornaría difícil en aquella zona, pero la mujer no quiso irse.

Mientras Toño estuvo en el Ejército, siempre tuvo afecto hacia los hijos de Wilson y Paulina, de quien siguió enamorado, lealtad y persistencia que es coherente con el sentido de rectitud que lo llevó a decirle al sargento que escuchaba disparos y explosiones en el pueblo, donde estaba su mamá. El sargento (evidentemente informado de la presencia de los paramilitares en aquel lugar) le ordenó rabiosamente no insistir, por lo cual Toño (en emotiva reacción) lo degolló y, como es obvio, tuvo que huir. La mamá de Toño fue asesinada pero Paulina se salvó y se dispuso a huir con sus dos niños. En ese punto ella y él se encontraron y pese a los desplantes de ella, Toño y Paulina llegaron juntos a Bogotá, pauperizados y desamparados. Las dos líneas paralelas se juntaron, un habitante de la calle intentó prostituir a Paulina y aunque Toño quiso ser indiferente, fue dominado por un celoso orgullo que lo llevó a trenzarse en una mortal lucha con aquel hombre.

De cualquier manera, también son importantes el tipo de acciones seleccionadas y la manera de ponerlas en escena audiovisualmente, como lo ha demostrado, entre otros, Jairo Pinilla, en obras como Funeral siniestro (1977) y como queda en evidencia en un sinnúmero de obras que recurren a la narración basada en los lugares comunes del comportamiento humano.

\section{Resultados}

La anterior identificación de cada uno de los componentes de la "red conceptual de la acción" permite identificar a los caracteres temporales o hechos históricos más aludidos 
por las obras cinematográficas colombianas. Revisando a las obras cinematográficas arriba aludidas y contrastando a esta lista con el catálogo de la fundación patrimonio fílmico colombiano ${ }^{6}$, en el cine hecho en Colombia es evidente una ausencia de obras que refieran los tiempos precolombinos y sobre la llegada de Colón a América solo existe una animación de 63 minutos realizada por Fernando Laverde con el título de Cristóbal Colón (1983); tampoco se encuentran obras sobre la Colonia (salvo algunos cortometrajes en video producidos recientemente por la Universidad del Cauca) y sobre la independencia destacan las series de obras unitarias ideadas por Gabriel García Márquez y producidas en soporte de celuloide para televisión con los títulos de Crónicas de una generación trágica (Triana y Restrepo, 1993) y De amores y delitos (1995). Sobre este mismo período se destacan dos obras sobre Bolívar: una en tono de parodia, Bolívar soy yo (Triana, 2002a) y la otra animada Bolivar, el héroe (Rincón, 2003).

Se carece igualmente de obras cinematográficas sobre los tiempos del establecimiento de la República y en general sobre el resto del siglo XIX, salvo si se considera a María (Calvo, 1922), imposible de reconstruir, o acaso por la alegórica La pobre viejecita (Laverde, 1980) y por la sátira burlesca San Antoñito (Sánchez, 1985). El primer gran hecho histórico del siglo XX, aludido directamente en el cine, es el traspaso del canal de Panamá a manos de los Estados Unidos, mediante la obra Garras de oro (Jambrina, 1926), que al parecer fue filmada en Italia ${ }^{7}$. Sólo en la última década del siglo, Camila Loboguerrero hizo María Cano (1990), una obra biográfica sobre la líder sindical del primer cuarto del siglo XX. Entre varios registros documentales de comienzos del siglo XX, destaca el que realizaron los hermanos Acevedo (1930) sobre la guerra contra el Perú y aunque sin aludir a eventos épicos ni heroicos, Flores del valle (Calvo, 1941), en 67 minutos da cuenta de algunos rasgos culturales del valle, como Bajo el cielo antioqueño (Acevedo, 1925) lo hace de la aristocracia antioqueña de aquella época.

Es el asesinato de Jorge Eliécer Gaitán (1948) el hecho que empieza a llamar la atención del cine colombiano con mayor fuerza, aunque 65 años después no se ha abordado este hecho de manera directa. Sin embargo, Canaguaro (Kusmanich, 1981) se refiere a hechos derivados de la muerte del mencionado político. En Cóndores no entierran todos los días (Norden, 1984), León María Lozano es un personaje surgido precisamente durante el periodo de violencia desencadenado, a raíz de la muerte del llamado "caudillo del pueblo". En Confesión a Laura (Osorio, 1990) son francotiradores amotinados a causa del asesinato de aquel político el 9 de abril del año mencionado, los que físicamente le impiden a Santiago salir de la casa de Laura.

En Un tigre de papel (Ospina, 2007), el historiador Arturo Alape afirma que Pedro Manrique Figueroa anduvo ese día cerca al lugar de los hechos. La historia del baúl rosado (Gómez,

6 Entidad auspiciada por el Estado colombiano para proteger y preservar al patrimonio audiovisual producido en Colombia. Para el efecto se apoya en la constitución nacional y en la legislación vigente acerca del cine.

7 Aunque en 1915 se había filmado El drama del 15 de octubre, sobre el asesinato de Rafael Uribe pero este no es un largometraje, lo cual no obsta para que no sea una obra significativa en la historia del cine nacional. 
2005) transcurre en años previos a la muerte de Gaitán y en esta obra se observan unos retratos de político (tipo cartel, pegados en una pared en un parquecito) por donde pasa el detective Mariano Corzo, cuando va hacia la casa de Martina, la dueña del café. Roa (Baiz, 2013) es quizá la obra que más se ha acercado al hacer referencia, al presunto autor material de aquel magnicidio.

Un hecho posterior aludido circunstancialmente en Carne de tu carne (Mayolo, 1983) es la explosión de unos camiones del Ejército cargados de dinamita, ocurrida el 7 de agosto de 1956 en Cali, hecho que marcó a la historia de esa ciudad. Este acontecimiento tuvo lugar durante la dictadura de Gustavo Rojas Pinilla, quien había dado un golpe de Estado en 1953. En Un tigre de papel (Ospina, 2007) se afirma que Pedro Manrique Figueroa presenció la represión de la policía rojista a los estudiantes. La llamada "violencia" liberalconservadora que se desgranó del asesinato de Gaitán es un período que está menos referido de lo que sería deseable, salvo por algunas obras como la ya mencionada Cóndores no entierran todos los días (Norden, 1984) o El río de las tumbas (Luzardo 1964) en la que se puede interpretar que los muertos sin identificación que bajan por el río y que descubre el bobo del pueblo, son víctimas de la violencia liberal conservadora que azotaba al país en aquellos años.

Un documental, Camilo, el cura guerrillero (Norden, 1974), aporta otros rasgos de las mentalidades de aquellos años, a partir de la interpretación que diferentes actores sociales y políticos hacen de aquel personaje, muerto ocho años atrás. Desde la cosmovisión indígena, Nuestra voz de tierra, memoria y futuro (Rodríguez y Silva, 1981) contribuye a ampliar la mirada sobre la historia en una época en que el movimiento indígena se ha venido consolidando organizativamente en Colombia. Con su música a otra parte (Loboguerrero, 1984) agrega algo más sobre el dilema entre la frivolidad y el romanticismo juvenil de izquierda en los años sesenta y setenta. Raíces de piedra (1961) y Pasado el meridiano (1966), ambas de José María Arzuaga, dan cuenta del paisaje urbano y de cierta moral sociopolítica de aquellos años en Bogotá. También para los años setenta y ochenta, Un tigre de papel (Ospina, 2007) complementa el registro de hechos significativos para una mirada global a la historia nacional, a partir de hechos ocurridos en Bogotá, y que se proyectaban o pretendían proyectarse sobre el acontecer nacional.

En los años setenta algunas obras zahirieron denunciando a la pobreza, como Gamín (Durán, 1977). Otras, en cambio, optaron por ensalzar a la frivolidad de la clase media, como Esposos en vacaciones (Nieto, 1978) y otras más a veces con asocio de algunos extranjeros de mirada exotista, fantasearon pese a las precariedades técnicas para elaborar tales relatos, narrativamente atrevidos pero de resultados bizarros como Holocausto caníbal (Deodato, 1981), Amazonas para dos aventureros (Hofbauer, 1974) e incluso Amenaza nuclear (Osorio, 1981). En ellas, de todas maneras (más allá de las particularidades expresivas de sus autores) se traslucen valores tanto tecnológicos como morales de la época.

Veinte años después de los hechos, se proyectó La toma de la embajada (Durán, 2000) en la que un comando del grupo guerrillero M-19 irrumpió el 27 de febrero de 1980 en una reunión de diplomáticos en la embajada de la República Dominicana, tomando como 
rehenes a varios embajadores. También había sido Ospina, esta vez en Soplo de vida (1999), quien había aludido a la catástrofe del Municipio de Armero que tuvo lugar el 13 de noviembre de 1985, al idear un personaje desaparecido aquella fatídica noche. Por su parte Baiz en Satanás (2007), recontó la masacre que cometió Campo Elías Delgado, un veterano de la guerra del Vietnam, el 4 de diciembre de 1986 en un restaurante de Bogotá. Un aspecto del conflicto social de los ochentas y quizá también de los noventas entre ricos y pobres quedó narrado en La estrategia del caracol (Cabrera, 1993) inspirada en una noticia sobre el desalojo de los inquilinos de una antigua casa, en la década del ochenta.

Aunque es notoria la ausencia de obras sobre los orígenes y los protagonistas del conflicto armado de los años subsiguientes a los de la violencia liberal-conservadora, es decir, el de las guerrillas de influencia socialista (junto con la ya mencionada sobre la toma de la embajada de República Dominicana) hay un panorama de este conflicto en un conjunto de obras, tales como Golpe de estadio (Cabrera, 1998) que entremezcla las afujías durante un combate entre el Ejército y la guerrilla con las reacciones emocionales de los combatientes de ambos bandos que, al mismo tiempo, observan algunos partidos del equipo nacional de fútbol. En La primera noche (Restrepo, 2003) aparece la connivencia de algunos integrantes de las fuerzas armadas del Estado con los paramilitares, mientras que en La pasión de Gabriel (Restrepo, 2009) se presenta la complementariedad por oposición entre el abuso de poder de la burocracia y la soberbia de un grupo guerrillero.

La sombra del caminante (Guerra, 2004), por su parte, señala la miseria en la que se encuentran tanto la víctima como el victimario en una ciudad que sigue su marcha caótica y también violenta. En Los actores del conflicto (Duque, 2008) se engranan diferentes lastres del conflicto: mafias, sectarismos, tráfico de armas, ineptitudes, soberbias y hasta impostaciones. En Yo soy otro (Campo, 2008) se remarca la presencia del conflicto en todos los lugares y aspectos de la vida social, mientras que en Los colores de la montaña (Arbeláez, 2010) se señala la frustración y el desplazamiento que victimizan a los campesinos y especialmente a los niños.

En El rey (Dorado, 2004) se dan datos sobre los comienzos del cultivo de marihuana y de la producción de cocaína. Por su parte, La ley del monte (Castaño y Trujillo, 1998), un documental de 62 minutos, describe los pasos de la compra de materia prima y producción de cocaína. Sumas y restas (Gaviria, 2004) alude a los tiempos y movimientos del tráfico del alcaloide y al encantamiento que este negocio ejerció sobre la clase media de Medellín en los ochentas y noventas hasta hacer sucumbir en su vorágine a muchos de sus pujantes prospectos empresariales. María llena eres de Gracia (Marston, 2004), detalla tanto la técnica de transporte humano de cocaína como las motivaciones y tormentos de quienes la practican, es decir, de las llamadas "mulas". En El arriero (Calle, 2009) se ocupa precisamente de la ética perversa y los ideales de un personaje que organiza y controla a tales mulas.

Rodrigo D: No futuro (Gaviria, 1990) mostró la osadía tanática asumida por los jóvenes sicarios de Medellín, para quienes solo cuenta la posibilidad de obtener un botín en el fugaz presente. La virgen de los sicarios (Schroeder, 2000) acentuó no solo la frialdad de los 
adolescentes para matar, sino también la pobreza en que viven y lo que es más importante, el curtido desarraigo en el que la única atadura es aquella peregrina fe siniestra puesta en el mito de la virgen. Precisamente Rosario tijeras (Maillé, 2005) resalta ese salvajismo urbano, esta vez con una mujer entre sus protagonistas.

En Karmma, el peso de tus actos (Pardo, 2006) se alude al flagelo del secuestro como aventura de la ambición, mientras $P V C$-1 (Stathoulopoulos, 2008) recrea el siniestro caso ocurrido el 16 de mayo del año 2000, cuando un grupo de delincuentes irrumpió en una finca y uno de ellos le instaló un collar explosivo a una mujer para presionar a su esposo a conseguirles una cuantiosa suma de dinero; Porfirio (Landes, 2011) muestra las ilusiones y las desgracias de un hombre que quedó inválido a causa de una bala perdida durante un tiroteo de la policía y que el 12 de septiembre de 2005 secuestró un avión para llamar la atención del gobierno, que no ha querido atender su demanda. Las alusiones al terror llegan hasta Silencio en el paraíso (García, 2011), una obra que se presenta como una historia de amor en la que la suerte del protagonista permite hacer referencia a la masacre de 18 jóvenes (aunque dentro de este relato solo asesinan a 8) acaecida a finales del 2008 en el municipio de Soacha, a manos de fuerzas del Estado, según se dice, presionadas a presentar resultados.

\section{Conclusiones}

En esta perspectiva, es notorio que no existen obras cinematográficas colombianas que aborden directamente al problema agrario, considerado una de las claves de los orígenes del conflicto social armado. En cambio, vale la pena referenciar a varios de los recursos simbólicos (referentes de interpretación) presentes en las obras cinematográficas estudiadas: el gamonalismo y la doble moral provinciana fue retratada por La virgen y el fotógrafo (Sánchez, 1982) pero la corrupción política y burocrática, centrada principalmente en Bogotá, ha sido un tema recurrente, por ejemplo en la populista Mamagay (Gaitán, 1977) en la que el poder y el oportunismo intentan sacar partido de un humilde albañil gratificado por la fortuna con el premio mayor de una lotería. Con mayor sentido épico y sugestividad, en Canaguaro (Kuzmanich, 1981) se muestra desde los llanos orientales de Colombia, cómo la rebeldía de unos se convierte en pretexto para que otros saquen ventaja personal.

La gente de La Universal (Aljure, 1991) es narrada con planos de audacia estilística, aunque no hay propiamente corrupción relacionada con la burocracia estatal, la mentira, la picardía y la infidelidad, las cuales subyacen como marcas de la moral social. Con esas reglas Diógenes Hernández paradójicamente indaga cierta verdad y su sobrino Clemente le aplica las mismas pautas a él. En Perder es cuestión de método (Cabrera, 2005) Víctor Silampa descubre el laberinto de relaciones y tráfico de influencias con las que en el fondo se construye la ciudad. La corrupción burocrática y el deterioro moral de la sociedad se compaginan hasta demoler a los más honestos, a la manera del llamado género del "cine negro" adaptado a Colombia. En El Colombian Dream (Aljure, 2006) contada con osados juegos sonoros pero sobre todo visuales y dramatúrgicos, la deshonestidad permea los más íntimos rincones de la familia y hasta dos de los llamados símbolos patrios son resignificados 
por el narcotráfico: la bandera, por medio de pastillas amarillas, azules y rojas; y el himno nacional por medio de una canción al patrón; sin embargo, sarcásticamente, esa es la realidad que desea el nonato Lucho para cuando llegue a este mundo.

En Perro come perro (Moreno, 2008) se produce el señalamiento alegórico de la ambición incrustada en la sociedad. El "Orejón", neurótico e implacable tiene sólo unos pocos valores, entre ellos principalmente un botín y la venganza. Por su parte, Peñaranda justifica su felonía con la noble causa consistente en asegurar el futuro de su pequeña hija, como en una proclamación de la consigna "el fin justifica los medios", mientras Benitez espera estoicamente la oportunidad de quedarse con todo, como en un irremediable acomodo a lo que pareciera no tener solución. Corruptos también son Uldarico y Bernardo en la comedia sarcástica Nochebuena (Loboguerrero, 2007), el primero adulterador de estrategias burocráticas y el segundo, usufructuador de dineros ajenos. En todo caso, ambos manipuladores de afectos personales y familiares.

Por otra parte, una es la violencia predestinada, como en la solemne Tiempo de morir (Triana, 1985), obra en la que aparece una violencia que sin hacer alusión a un lugar específico ni a una teleología particular, brota de una cierta predisposición del macho hacia la violencia y al ataque. Así le sucedió a Juan Záyago al matar a Raúl Moscote, lo mismo le sucedió a Julián Moscote, quien murió al intentar la venganza de su padre y ese fue el destino inevitable de Pedro al matar a Juan. La madre de los Moscote, la amante de Julián y la mujer de Pedro (en tanto mujeres) permanecen como confidentes o consejeras de las decisiones de vida y muerte. Igualmente, en Edipo alcalde (Triana, 1996) aunque rítmicamente desigual, hay una recontextualización de la tragedia clásica en la Colombia contemporánea, dado que tanto guerrilleros como paramilitares hacen parte del destino ya descrito por el oráculo, un fabricante de ataúdes, acaso mensajero de la muerte; Layo, el gobernante, inevitablemente, muere en un tiroteo, Edipo, alcalde de Tebas, se casa con la viuda Yocasta pero al darse cuenta de su incesto, se arranca los ojos y termina deambulando como mendigo en medio de la violencia socioeconómica de Bogotá, tan desgraciada como las otras violencias.

En cambio, otra es la violencia que se aprecia en Cóndores no entierran todos los días (Norden, 1984) afincada dramatúrgicamente en la referencia a un acontecimiento concreto de la historia colombiana; ligada al apasionamiento partidario, al conservadurismo históricamente vinculado con un catolicismo recalcitrante y a la estructura gamonalista de la sociedad, todo lo cual propicia que se busque controlar el poder mediante mediciones de temperamento y de fuerza.

Las obras relacionadas con el conflicto armado también refieren una violencia ubicada histórica y socialmente aunque en la dramáticamente intensa y visualmente delicada $L a$ sombra del caminante (Guerra, 2004) parece haber una denuncia de la inutilidad de la violencia política porque, en el fondo, lo que hay es una violencia cultural que se vive en las calles, por donde unos muchachos golpean a Mañe aprovechando que es lisiado, la policía persigue al silletero (que es analfabeto) y que de ser victimario de la familia de Mañe pasa a ser su víctima cuando aquel esconde la planta de cuya infusión depende su 
vida. Entonces parece que no queda más alternativa que convivir y (preguntarnos si) en medio del abigarramiento social acaso es posible el perdón.

No obstante, PVC-1(Stathoulopoulos, 2008) aunque más interesada en la formalidad del plano secuencia que en los personajes, muestra la brutalidad y la crueldad de unos delincuentes que (en busca de su propio lucro) someten a una intensa tortura psicológica a una familia, cuya madre muere, en parte por la falta de una reacción institucional eficaz, representada por la parsimonia del experto en explosivos. Una saña similar se observa en las mutilaciones con motosierra que se observan en Perro come perro (Moreno, 2008). Una parsimonia burocrática análoga se entreteje en Todos tus muertos (Moreno, 2011).

La pobreza como denuncia del fracaso del ideal humanista aparece en Raices de piedra (Arzuaga, 1961) en la que el progreso en una ciudad (que por lo demás, al ser capital de la República lidera al proceso de urbanización nacional consecuente al periodo de desplazamiento causado por la violencia liberal-conservadora) no es para nada equitativo. Firulais es un ladronzuelo y escasamente sobrevive. Clemente trabaja arduamente y no vive mejor. Este último se accidenta y Firulais busca medicamentos, pero la tarea resulta muy difícil. Tampoco encuentra solidaridad y cuando regresa, su amigo ya ha muerto. Augusto en Pasado el meridiano (Arzuaga, 1964) es sometido a la indolencia de su jefe, que nunca llega para autorizarle que asista al velorio de su mamá y mientras tanto la ciudad sigue su rumbo incontenible e insolidario. Poder y progreso se confabulan para ensalzar a unos y humillar a otros. De todas maneras, en estas últimas dos obras (técnicamente imperfectas, pero conceptualmente muy expresivas) la pobreza aparece como sufrimiento.

En cambio, en un tono no menos trascendental (pero sí con humor y fluidez narrativa) $L a$ estrategia del caracol (Cabrera, 1993) alcanza mayor complejidad. El conflicto central consiste en que Holguín desea a la antigua casa para construir allí un proyecto urbanístico más rentable, mientras los moradores de ella reclaman el derecho a la vivienda, adquirido en forma consuetudinaria. El apabullante ideal de progreso se enfrenta al ideal de la igualdad y de esa manera la función de la propiedad privada queda en el centro de la disputa. Jacinto y Perro Romero asumen a la pobreza con la lucha social, en contraste con personajes como doña Eulalia quien la vive como padecimiento personal. En esta obra, la pobreza también es un contexto cultural en el que un mosaico de personajes urbanos (algunos con cierta raigambre rural) hacen gala de su coraje y sobretodo de su picardía para sobrevivir, que es con la que finalmente invaden otro terreno, desvalijan la casa, destruyen la fachada y entregan el lote con una "casa pintada".

En La sociedad del semáforo (Mendoza, 2010) se enfatiza precisamente en las construcciones culturales de los pobres, en este caso, en las de quienes rebuscan su subsistencia en los semáforos, construcciones (de cualquier manera) estridentes frente al clasicismo estético y al civismo. Raúl Trellez se propone manipular el tiempo que duran los semáforos en rojo para ampliar la posibilidad de desempeño de los artistas y vendedores callejeros, con lo cual el significado de aquellos objetos urbanos se traslada desde la regulación de la movilidad urbana hasta llegar a ser un fenómeno casi natural, lejos de cualquier cuestionamiento a la estructura sociopolítica, aunque haya algunos lamentos ante la suerte de ser pobre. 
Ahora, si las anteriores obras se alejan del maniqueísmo según el cual todos los pobres son buenos, porque por ejemplo, incluso el sufrido y solidario Firulais de Raíces de piedra (Arzuaga, 1961) lleva el estigma de ser un ladrón, por su parte Como el gato y el ratón (Triana, 2002) acentúa o quizás exacerba esta complejidad y, muy al contrario, muestra a las familias Cristancho y Brochero, desplazadas y pauperizadas, que se envuelven en la intolerancia y paulatinamente caen en la rabia, la envidia, la agresión, la traición y la venganza, como si sus comportamientos fueran una caja de Pandora, hasta conducir a todo el barrio (ciertamente abandonado por el Estado) a la destrucción de lo que había sido su mayor logro: instalar la electricidad, invento que caracteriza a la modernidad. Hasta Esperanza y Consuelo (alegóricos nombres de las esposas de Miguel y Cayetano) se trenzan en una fatal pelea que no logra contener Kennedy, el ecuánime edil.

Hubo en Flores del valle (Calvo, 1941) una mujer campesina que dejó constancia de su amor propio al demostrar que era capaz de ser bailarina urbana y luego regresar a su tierra. Sin embargo, acerca de la mujer, en el cine es frecuente el uso de arquetipos, como el de la mujer fatal, esencialmente erotizada y al mismo tiempo manipuladora. La abuela (Pinzón, 1981) no menos truculenta, presenta a una mujer anciana adinerada y neurótica, lo cual tampoco deja de ser un cliché. María Cano (Loboguerrero, 1989) busca otra alternativa narrando, aunque sin mucho temperamento, a una mujer que sí lo tuvo: María Cano acometió poemas (oficio en el que no alcanzó mucha resonancia) pero sobre todo se dedicó durante buena parte de su vida a la lucha social, organizando a obreros y campesinos en tiempos en que nació el sindicalismo en Colombia, actividad que le granjeó el apelativo de "la flor del trabajo". En un tono tan diletante como el personaje principal de Ilona llega con la lluvia (Cabrera, 1996) presenta a otra mujer muy erotizada pero también libertaria y cosmopolita, desestabilizadora de la masculinidad patriarcal. En cambio, La vendedora de rosas (Gaviria, 1998) refleja una desgracia contemporánea: Mónica es una niña, rebelde, pobre, que se desplaza por las calles entre su barrio y el centro de la ciudad de Medellín donde vende rosas que representan un amor que no tuvo y que no logra superar su mayor adversidad, el desamparo, en el que muere.

La joven María en María llena eres de gracia (Marston, 2004) es un caso de fuerza de voluntad, orgullo y emancipación personal porque aunque ella también es pobre y se encuentra incómoda viviendo con su familia, se niega a seguir permitiendo que la exploten en una plantación de flores y se convierte en transportadora de cocaína, como la mayoría de "mulas" por necesidad económica. Sin embargo, una vez llevada la mercancía a su destino, se evidencia que su sentido de dignidad es mayor que la ambición monetaria y se queda (aunque ilegalmente) para iniciar con el hijo que espera una nueva épica de en la cotidianidad. En Rosario tijeras (Maillé, 2005) obra más espectacular que reflexiva, la trágica suerte de Rosario la hace víctima de la violencia sexual desde pequeña, cuando es violada y también de joven cuando es vendida; su entorno cultural en las comunas populares es violento y ella (además de temperamental) es astuta y arriesgada. De ahí que desarrolle un siniestro y comprensible sentido de la venganza y la sevicia, que a la postre también la llevan a la muerte.

PVC-1 (Stathopoulus, 2007) es otro caso de violencia contra la mujer, esta vez con mayor frialdad (pero no menos terror) que no le da a Ofelia (de extracción campesina) posibilidades 
de salvar su vida. Vega, en Al final del espectro (Orozco, 2006) es una mujer joven, de clase media alta, acorralada por sus angustias; Karen llora en un bus (Rojas, 2011), mediante puestas en escena de teatralidad básica, reivindica a la mujer madura (de clase media alta) que no tiene penurias económicas, como sí sucede con Mónica y María, ni el entorno violento de Rosario y Ofelia: no es tan liberal como Ilona, pero tampoco está interesada en ser manipuladora como Miranda o la abuela. Sencillamente quiere ser autónoma (como casi todas ellas) aunque también tenga que pasar por las dificultades de todas ellas.

Las mujeres han aparecido también en relación con el desplazamiento, como Paulina en La primera noche (Restrepo, 2003), continua sus ecos en Retratos en un mar de mentiras (Gaviria, 2010), en la que Jairo acompaña a su prima Marina (una joven que padece secuelas de la guerra) en el intento de recuperar unas tierras legítimamente heredadas. En La sirga (Vega, 2012), en la que Alicia (otra mujer joven y victimizadas) también se enfrenta al futuro, esta vez de manera estoica y lejos de los ajetreos de la salvaje civilización. En Chocó (Hinestroza, 2012), en la que una mujer afroamericana y pobre lucha contra las adversidades que le marcan esas tres condiciones.

Gamín (Durán, 1977) relata con más crudeza que análisis las audacias y patetismos de varios niños que viven en las calles de Bogotá. Según se afirma, algunos de ellos han escapado de sus casas, con lo cual, indirectamente se reivindica la importancia de la familia y se acusa el deterioro de la misma. Recurriendo al melodrama, El niño y el Papa (Castaño, 1987) relaciona las carencias afectivas de un niño con la fe (al parecer innata) para así encontrar a su madre, amnésica a consecuencia del terremoto de México (1985). A la salida nos vemos (Palau, 1986) recrea con nostalgia algunas anécdotas de la infancia escolar en la ciudad de Cali, bajo la batuta de valores familiares entre provincianos y modernos. En La vendedora de rosas (Gaviria, 1998) el ritmo de cada plano se corresponde con el de toda la obra y acompaña a Chinga (un niño precoz) y que resalta la existencia de las niñas (Andrea, Judy, Cachetes) todas ellas rebeldes, pero contextualizadas en la problemática de las familias pobres.

Aunque no lo parezca, Los niños invisibles (Duque, 2001) es una comedia política: entretiene con un humor arraigado en la contravención de la moral confesional de los cincuentas por parte de unos niños fantasiosos y crédulos. Asimismo, deja ver en el trasfondo varios contextos culturales como los tiempos de la dictadura rojista, los inicios de la televisión en Colombia y algunos matices de la violencia social y política. La épica nacional vuelve a parecer en Los colores de la montaña (Arbeláez, 2010) que destaca en forma conmovedora el candor de Manuel y Pocaluz, unos niños campesinos aficionados al fútbol, mientras el conflicto armado pasa por su lado, obstruyendo la labor de una joven profesora, destruyendo las familias y arrasando con las fincas.

Aparte de los acercamientos que las obras hacen hacia la infancia y la familia, las veleidades de una familia aristocrática de comienzos de siglo se cuelan en el relato melancólico de $E l$ día que me quieras (Dow, 1986). Las rutinas de la familia de clase media urbana quedan aludidas mediante los lugares comunes y chascarrillos de Mi abuelo, mi papá y yo (García y Vásquez, 2005): Óscar flirteando con Elizabeth, Eduardo divorciándose de Myriam y 
Rubén buscando a Esperanza. La clase media-media se registró en las frivolidades de El carro (Orjuela, 2003) y El paseo (Trompetero, 2010), desafinado viaje de la familia de Hortensia y Alex Peinado hacia Cartagena. En cambio, Paraíso Travel (Brand, 2007) plantea mayores complejidades en la familia de extracción popular, a través de las torpezas emocionales de Marlon, quien se deja extraer de su convencional familia por los caprichos de Reina, quien, a su vez, es parte de una familia disuelta. Con humor mordaz, Nochebuena (Loboguerrero, 2007) se encarga de una aproximación a una familia burguesa sostenida por la hipocresía y en decadencia económica.

La juventud ha sido un asunto poco explorado por el cine colombiano en forma directa. No obstante, desde el cine silente es más frecuente encontrar historias que involucran a los jóvenes, ya sea a través del amor, como en Bajo el cielo antioqueño (Acevedo, 1925) y Alma provinciana (Rodríguez, 1925); del crimen, como en las obras que aluden al sicariato; como parte de una familia, como en Mi abuelo, mi papá y yo (García y Vásquez, 2005) o en Paraíso Travel (Brand, 2007) en la que se observa la relación entre la tenacidad juvenil y las rupturas familiares: la de la temperamental Reina, quien fue a buscar a Raquel, su madre alcohólica, y la de Marlon, el joven que madura con los golpes que le depara la abigarrada Nueva York; o enredados en cualquier otra circunstancia como en los actores del conflicto. Una de las pocas obras que alude a la juventud directamente es San Antoñito (Sánchez, 1985) sobre un bribonzuelo de la sociedad confesional y pueblerina antioqueña de finales del siglo XIX. En contraste, Rodrigo D: No Futuro (Gaviria, 1990) explora el mundo sombrío y sin salidas de los jóvenes de las comunas populares en la urbanizada Medellín (capital de Antioquia) a finales del siglo XX.

La búsqueda de nuevos horizontes individuales o familiares ha tomado alternativas en el exilio, como lo intenta el adolescente Adolfo en la comedia Visa USA (Duque, 1986) aunque después de las tortuosidades del primer viaje de todo provinciano que finca sus esperanzas de redención social en la capital, no logra ni siquiera la visa; para consuelo suyo su novia Patricia escapa a la vigilancia de sus padres y ambos (jóvenes pueblerinos) tan solo encuentran exilio en Bogotá. En La nave de los sueños (Durán, 1996) el sueño de llegar a Estados Unidos, referente de progreso en la época, sí se realiza. Los seis polizones (seres desahuciados por la sociedad) llegan a Estados Unidos, quizás porque tienen más arrestos para relucir sus historias de vida, sus egoísmos y sus solidaridades. Entre la cotidianidad de una familia y la psicología de un personaje, El séptimo cielo (Fisher, 1999) no deja de ser una historia aleccionadora para quienes deseen emigrar; aunque la familia de Joselito sobrevive en Nueva York (con conciencia de las dificultades) él, especialmente susceptible, padece las humillaciones de ser un ciudadano latino y las nostalgias de estar fuera de su país: en Nueva York no solo hay glamour, también hay sordidez y violencia.

Aunque al comienzo de su historia no planea emigrar, la personaje principal de María llena eres de gracia (Marston, 2004) cuando logra el llamado "sueño americano" sí está muy segura de su propio sueño y también está segura de no continuar empleando su cuerpo para el narcotráfico, así no sepamos qué haya podido sucederle después de tomar la decisión de quedarse en USA. Esa emancipación, económica y familiar, en este caso, parecen 
haberla alcanzado ya Pastor y Patricia, los dueños del restaurante "Mi Tierra colombiana", contrapunto de quienes ingresan para actividades ilegales o de baja reputación. Ellos le dan empleo y protección a Marlon en Paraíso Travel (Brand, 2007), obra en la que se detallan cruentas vicisitudes de la travesía para entrar a Estados Unidos y la gama de personajes neoyorquinos, estridentes, unos, como Roger y la misma Raquel e incluso la Caleña; providenciales otros, como Milagros, Patricia, Pastor, Giovanny y Hernán. Por otra parte, en El arriero (Calle, 2009), Ancizar López hizo el doble recorrido de salir de la pobreza "exportando cocaína" (en este caso a España) y luego renunciar al estatus económico logrado hasta convertirse en uno de estos personajes aparentemente anodinos, pero que llevan a cuestas las historia personales con las que se ha tejido la historia.

Muy cerca a la temática del exilio está el de la calle, como en Buscando a Miguel (Fisher, 2007), arrítmico llamado a la conciencia burguesa por medio de la resurrección de Miguel: un joven político que se ve enfrentado a las miserias urbanas que en vida desconoció y subestimó. A la inversa del mito católico, Miguel no resucita para ascender al cielo (luego de haber padecido sufrimiento) sino que llega del cielo en el que vivió para soportar el mundo de los miserables, quienes, sin embargo, lo redimen. En La primera noche (Restrepo, 2003) ya se habían visto los padecimientos de dos campesinos desplazados que llegan a la capital, mientras que La vendedora de rosas (Gaviria, 1998) había escudriñado más que los padecimientos, los intríngulis socioculturales de la vida callejera (especialmente la nocturna) en la ciudad de Medellín. Y mucho más antes, Gamín (Durán, 1977) había descrito las peripecias instintivas de los pequeños habitantes de la calle en la Bogotá de los años setenta.

Hay varias obras cinematográficas centradas en historias de amor, como la melodramática Bajo el cielo antioqueño (Acevedo, 1925), que destaca al honor de Álvaro y Lina. La segregacionista Alma provinciana (Rodríguez, 1925), que afianza al clasismo burlándose de los acercamientos amorosos entre patronos y jornaleros. La sentimentalista Tiempo para amar (Álvarez, 1980), en el que una monja (la hermana Pili) descubre su vocación por el amor romántico y carnal. En la estereotipada Una mujer con suerte (Nieto, 1991), María Elena Sevilla (una cantante, separada) redime su vida matrimonial con Antonio Contreras. Bésame mucho (Toledano, 1995), obra en la que una mujer malquerida por su esposo se redime en una pasión intempestiva y poco convincente con un desconocido.

En la mordaz Visa USA (Duque, 1986), la redención se da con el reencuentro de Adolfo y Patricia en Bogotá, luego que ella se fugó de la casa. En Confesión a Laura (Osorio, 1990), el mismo fenómeno adquiere tonos psicosociales al presentar el encuentro de dos personas maduras (Santiago y Laura) que rompen las ataduras de los convencionalismos y se redimen a sí mismos, aún en medio de los motines generados por un magnicidio. En Diástole y sistole (Trompetero, 1999) tal visión redentora se invierte y el amor resulta un juego a menudo ramplonamente manipulador entre dos seres anónimos, de los que solo se destacan sus egoísmos. Terminal (Echeverri, 2000) tiene la característica de presentar como protagonista a un hombre (Julián) quien entre el estoicismo y la amargura no alcanza la redención, nunca reencuentra a Mara, mientras que en Malamor (Echeverri, 2003) es el desenfreno el que condena a Lisa a no alcanzar el amor. 
La intimidad, aparte de las obras de Echeverry (Malamor o Terminal) sin dejar de aludir al contexto sociocultural e histórico, es abordada por Fernández de Soto en Colombianos, un acto de fe (2004), una alegoría satírica del país y en Cuarenta (Fernández de Soto, 2011), una reflexión mordaz sobre la sociedad y la mistad. Por aparte, en Sofía y el terco (Burgos, 2012) presenta en una singular historia las veleidades del amor en la tercera edad en un lugar impreciso en el mundo.

\section{Fuentes consultadas}

Acevedo Vallarino, A. (1925). Bajo el cielo antioqueño [película]. Compañía Filmadora de Medellín.

\section{Aljure, F.}

_(2006). El Colombian Dream [película]. Sonica.

_(1991). La gente de La Universal [película]. Fotoclub 76 IMS (Colombia), Igeido Zine Produkzioak, Televisión Española, Euskal Media S. A. (España), Channel 4 (Inglaterra), Tehaplinhe Fli (Bulgaria).

Álvarez, M. (1980). Tiempo para amar [película]. Centauro Films, FOCINE.

Álvarez, M. y Buenaventura, N. (1997). La deuda. O la insólita muerte y no menos asombrosa resurrección y segunda muerte de Ali Ibrahim María de los Altos Pozo [película]. Abcine Nuevos Proyectos, Grupo Colombia, JB Publicidad, Tomas Zapata Producciones, Instituto Cubano del Arte e Industrias Cinematográficos (ICAIC), Les Films du Requin (Francia).

Andrade O. y Carrillo, J. (2010). Pequeñas voces [película animada]. RCN Cine, Films Boutique.

Arbeláez, C. (2010). Los colores de la montaña [película]. El Bus producciones.

\section{Arzuaga, J.}

_(1966). Pasado el meridiano [película]. Arpa Films.

_(1961). Raíces de piedra [película]. Cinematográfica Julpeña.

Baiz, A.

_(2013). Roa [película]. Dynamo (Colombia) y Patagonik Films (Argentina).

_(2007). Satanás. Perfil de un asesino [película]. Proyecto Tucán, Río Negro Producciones, Dynamo Capital.

Bordwell, D. (1985). Narration in the Fiction Film. Wisconsin: University of Wisconsin Press.

Bottia, L. (1985). La boda del acordeonista [película]. FOCINE, Grupo Cine Taller. 
Brand, S. (2007). Paraíso Travel [película]. Paraíso Pictures y Grand Illusions Entertainment.

Burch, N. (1987). El tragaluz del infinito, contribución a la genealogía del lenguaje cinematográfico. Madrid: Cátedra.

Burgos, A. (2012). Sofía y el terco [película]. Faldita Films, Imizu SAC.

\section{Calvo Olmedo, $M$.}

_(1941). Flores del valle [película]. Calvo Film Company.

_(1922). María [película]. Valley Film Company.

Castaño, R. (1987). El niño y el Papa [película]. Producciones Casablanca (Colombia), Cineproducciones Internacionales S. A. (México).

\section{Cabrera, S.}

_(2005). Perder es cuestión de método [película]. Tornasol Films, Latinia P. C.

_(1999). Golpe de Estadio [película]. Producciones Fotograma, Sésamo (Colombia), Emme S. R. L. (Italia), Tornasol Films (España).

_(1996). Ilona llega con la lluvia [película]. Producciones Fotograma, Caracol Televisión (Colombia), Emme S. R. L (Italia).

_(1993). La estrategia del caracol [película]. Caracol Televisión, Producciones Fotograma (Colombia), Emme SRL (Italia), Ministere Francais de la Culture et de la Francophonie, Ministere Francais des Affaires Etrangeres (Francia).

Calle, G. (2009). El arriero [película]. Fundación Lumiere, RCN Cine.

Campos, O. (2008). Yo soy otro [película]. ENIC Producciones, EFE-X Cine, Jaguar Films.

Castaño, P. y Trujillo, A. (1998). La ley del monte [película]. Citurna para ZDF y TVEUNEP.

Chatman, S. (1990). Historia y discurso. La estructura narrativa en la novela y en el cine. Madrid: Taurus.

\section{Coral-Dorado, $\mathbf{R}$.}

_(2002) Te busco [película]. Dago García Producciones.

_(1996). La mujer del piso alto [película]. Dago García Producciones.

Deodato, R. (1980). Holocausto caníbal [película]. Bolivariana Films (Colombia), F. D. Cinematográfica S. R. L.

Dow, S. (1986). El día que me quieras [película]. FOCINE, Productora colombiana de Películas (Colombia) y Publicidad Técnica Publiteca (Venezuela). 
Dorado, A. (2004). El rey [película]. Fundación Imagen Latina y Eurocine C. T. P.

\section{Duque Naranjo, $\mathbf{L}$.}

_(2008). Los actores del conflicto [película]. EGM Producciones (Colombia) y Ma Non Troppo (Venezuela).

_(2001). Los niños invisibles [película]. EGM Productions, Cinetel Ltda (Colombia), Ma non troppo films (Venezuela).

(1988). Milagro en Roma [película]. Elisa Cinematográfica, International Network Group S. A. (1986). Visa USA [película]. COCINE, Instituto Cubano del Arte e Industrias Cinematográficos (ICAIC), Producciones Plano General.

\section{Durán, C.}

_(2000). La toma de la embajada [película]. Producciones cinematográficas UNO (Colombia), Cineproducciones internacionales (México), Cinemateam (Venezuela), con la ayuda de IBERMEDIA.

_(1996). La nave de los sueños [película]. Producciones cinematográficas UNO (Colombia), Instituto Mexicano de Cinematografía IMCINE, Imágenes en movimiento Resonancia, San Pedro Post Producción, Laboratorios Churubusco, Artes Films, Cooperativa Río Mixoac (México), Centro Nacional Autónomo de la Cinematografía CNAC, Producciones Tango Bravo C. A. (Venezuela).

_(1977). Gamín [película]. Producciones Cinematográficas UNO (Colombia), Instituto Nacional Audiovisual INA (Francia).

\section{Echeverri, J.}

_(2003). Malamor [película]. Jorge Echeverry Producciones.

_(2001). La pena máxima [película]. Dago García Producciones.

(2000). Terminal [película]. Producciones Jorge Echeverry con el apoyo de la Dirección Nacional de Cinematografía, del Ministerio de Cultura.

_(1992). Tulia, de San Pedro de Iguaque [documental]. Jorge Echeverri.

\section{Fernández de Soto, C.}

(2011). Cuarenta [película]. Lulo Films.

_(2004). Colombianos, un acto de fe [película]. Cinetel.

Field, S. (1984). The Screenwriter's Workbook. Nueva York: Dell Trade Paperback.

\section{Fisher, J.}

_(2007). Buscando a Miguel [película]. Hidden Eye Productions.

_(1999). El séptimo cielo [película]. Hidden Eye Productions.

Gaitán Gómez, J. (1977). Mamagay [película]. Acemar División Cinematográfica (Colombia), Birongo Films C. A. (Venezuela).

García, C. (2011). Silencio en el paraíso [película]. Ocho y Medios Comunicaciones. 
García, D. y Vásquez, J. (2005). Mi abuelo, mi papá y yo [película]. Dago García Producciones.

García, R. (2000). Kalibre 35 [película]. Raúl García Cía.

\section{Gaviria, V.}

_(2010). Retratos en un mar de mentiras [película]. Producciones Erwin Goggel.

(2004). Sumas y restas [película]. Burn Pictures, Latin Cinema Group, La Ducha Fría Producciones, Latino Films. A. T. P. P. Producciones.

_(1998). La vendedora de rosas [película]. Producciones Filmamento y Producciones Erwin Goggel.

_(1990). Rodrigo D: No Futuro [película]. FOCINE, Producciones Tiempos Modernos Ltda y Fotoclub 76.

Gómez, L. (2005). La historia del baúl rosado [película]. Felis Films Ltda (Colombia), Moro Films (México), Oberón cinematográfica (España).

Guerra, C. (2004). La sombra del caminante [película]. Ciudad Lunar Producciones, Proyecto Tucán.

Guerra, R.; Basile, A.; Mora, P. y Sánchez, J. (2001). Bogotá 2016 [película]. Centauro Films de Colombia.

Hinestroza, J. (2012). Chocó [película]. Antorcha Films.

Hofbauer, E. (1974). Amazonas para dos aventureros [película]. Producciones Díaz Ercole, Tikuna films (Colombia), Danny Films (Italia), Regina films, Theo María Werner (Alemania).

Jambrina, P. (1926). Garras de oro [película]. Cali Film.

Kuzmanich, D. (1981). Canaguaro [película]. Alberto Jiménez, Corporación Financiera Popular FONADE.

Landes, A. (2011). Porfirio [película]. Carmelita Films, Campo Cine, Contro Z Films, Atopic.

Langdale, A. (ed.) (2002). Hugo Munsterberg on film. The Photoplay. A Psychological Study and Other Writings. Nueva York: Routledge.

\section{Laverde, F.}

_(1983). Cristóbal Colón [película animada]. FOCINE.

_(1978). La pobre viejecita [película animada]. Global Films de Colombia.

Lawson, J. (1949). Theory and Technique of Playwriting. Nueva York: G. P. Putnam's Sons. 


\section{Loboguerrero, $\mathbf{C}$.}

_(2007). Nochebuena [película]. Dynamo Producciones S. A., Producciones Nochebuena Ltda. _(1990). María Cano [película]. FOCINE.

_(1984). Con su música a otra parte [película]. FOCINE.

Luzardo, J. (1964). El río de las tumbas [película]. Cine Colombia, Cine-TV Films, Panamerican Films.

Maillé, E. (2005). Rosario tijeras [película]. Río Negro, United Angels, Dulec Compañía, Moonshot, La femme Endormie, Tafay S. L. y Maestranza Films.

Marston, J. (2004). María llena eres de gracia [película]. Tucán Producciones (Colombia), HBOFilms, Fine Line Features, Journeymann Pictures, Altercine (Estados Unidos).

Mayolo, C.

_(1986). La mansión de Araucaima [película]. FOCINE y Rodaje Ltda.

_(1983). Carne de tu carne [película]. Producciones visuales. FOCINE.

McCausland, E. (1998). El último carnaval [película]. La Esquina del Cine.

Mendoza, R. (2010). La sociedad del semáforo [película]. Dia Fragma Fábrica de Películas.

Moreno, C.

_(2011). Todos tus muertos [película]. 64-A Films.

_(2008). Perro come perro [película]. Antorcha Films, Patofeo Films.

Nieto Roa, G.

_(2007). Entre sábanas [película]. Centauro Films.

_(1991). Una mujer con suerte [película]. American Films Productions, Centauro Comunicaciones.

_(1979). El taxista millonario [película]. Centauro Films de Colombia, ABCine y Cine Colombia.

_(1978). Esposos en vacaciones (canas al aire) [película]. Mundo Moderno, Global Films de Colombia, Circuito Presidente.

Norden, F.

_(1984). Cóndores no entierran todos los días [película]. PROCINOR.

_(1974). Camilo, el cura guerrillero [documental]. PROCINOR.

Orjuela, L. (2003). El carro [película]. Dago García Producciones.

Orozco, J. (2006). Al final del espectro [película]. Paloalto Films.

Osorio Gómez, J. (1990). Confesión a Laura [película]. FOCINE (Colombia), ICAIC, FNCL (Cuba), TVE (España). 
Osorio, J. (1981). Amenaza nuclear [película]. Producciones Diaz Ercole, T. V. Cine Studio, FOCINE.

\section{Ospina, L.}

_(2007). Un tigre de papel [documental]. Luis Ospina, Congo Films, Efe-X.

_(1999). Soplo de vida [película]. Centro Nacional de Cinematografia, EGM Producciones, Fonds Sud Cinéma.

_(1982). Pura sangre [película]. FOCINE.

Palau, C. (1986). A la salida nos vemos [película]. Producciones Solsticio, Hangar Films, Compañía de Fomento Cinematográfico, Cinematográficas Macuto C. A.

Pardo, O. (2006). Karmma, el peso de tus actos [película]. Océano Films O. P. Ltda.

\section{Pinilla Téllez, J.}

_(1984). Triángulo de oro (La isla fantasma) [película]. Sonofilms.

_(1977). Funeral siniestro [película]. Asofilms de Colombia.

Pinzón, L. (1981). La abuela [película]. Dinavisión, Cine Colombia.

\section{Restrepo, L.}

_(2009). La pasión de Gabriel [película]. Señal creativa Ltda.

_(2003). La primera noche [película]. Congo Films.

_(1995). De amores y delitos: Bituima 1780 [película]. Centauro Films de Colombia.

Ribero, M. (1987). El embajador de la India [película]. Compañía de Fomento Cinematográfico de Colombia.

\section{Ricoeur, $\mathbf{P}$.}

_(2002). Del texto a la acción. Ensayo de hermenéutica I. México D. F.: Fondo de Cultura Económica.

_(2000). Tiempo y Narración I. México D. F.: Siglo XXI Editores.

_(1996). Sí mismo como otro. México D. F.: Siglo XXI Editores.

Rincón, M. y Sambrell, A. (1981). Kapax, el hombre leopardo (Mundo verde) [película]. Maro Films, Asbrell Production.

Rincón, G. (2003). Bolívar, el héroe [película animada]. RCN televisión, Guillermo Rincón, Bergen Hills Lic, Milena Calderón.

Rodríguez, F. (1925). Alma provinciana [película]. Félix Mark Films.

Rodríguez, M. y Silva, J. (1982). Nuestra voz de tierra, memoria y futuro [documental]. Instituto Cubano del Arte e Industrias Cinematográficos (ICAIC), Rodríguez-Silva. 
Rojas Vera, G. (2011). Karen llora en un bus [película]. Cajanegra Producciones.

Ruiz Navia, O. (2009). El vuelco del cangrejo [película]. Contravía Films, Diana Bustamante (Colombia), Arizona Films (Francia).

Sánchez, L. (1982). La virgen y el fotógrafo [película]. FOCINE y La Iguana Ltd.

Sánchez, P. (1985). San Antoñito [película]. Interimagen Cine TV, FOCINE.

Schroeder, B. (2000). La virgen de los sicarios [película]. Tucán producciones (Colombia), Le Studio Canal Plus, Les Films du Losange (Francia), Vértigo Films.

Stathoulopoulos, S. (2007). PVC-1 [película]. Goliath Entertainment, HDFilms, Hermano Films.

Toledano, P. (1995). Bésame mucho [película]. Producciones UNO (Colombia), Aries Films (México), Producciones Tango Bravo, Quiubo Films (Venezuela).

Triana, J.

_(2006). Soñar no cuesta nada [película]. CMO Producciones, Barakacine Producciones, Hangar Films, RCN Cine.

_(2002a). Bolívar soy yo [película]. United Angels Productions, Grupo Colombia.

_(2002b). Como el gato y el ratón [película]. Clara María Ochoa Producciones, Artcam International.

_(1996). Edipo alcalde [película]. Amaranta, Sogetel, IMC, Tabasco Film.

_(1985). Tiempo de morir [película]. FOCINE (Colombia), ICAIC (Cuba).

Triana, J. y Restrepo, L. (1993). Crónicas de una generación trágica [serie de televisión]. TVCINE y TELEVIDEO.

\section{Trompetero, $\mathbf{H}$.}

_(2010). El paseo [película]. Dago García Producciones.

_(2009). El Man, el superhéroe nacional [película]. RCN Cine y Ennovva.

_(1999). Diástole y sístole [película]. Comunicarte Producciones.

Vega, W. (2012). La sirga [película]. Contravía Films. 